\title{
十字型軸材を溶接組立箱形断面材で補剛した座屈拘束ブレースの ひずみ振幅の入力順序による損傷度影響評価
}

\section{DAMAGE EVALUATION CONSIDERING INPUT ORDER OF STRAIN AMPLITUDE FOR BUCKLING RESTRAINED BRACES WITH CROSS-SHAPED CORE AND WELDED BOX-SECTION MEMBER}

\author{
植木卓也 ${ }^{* 1}$, 北村春幸 ${ }^{* 2}$, 佐藤利 昭 ${ }^{* 3}$, \\ 佐藤大樹*4, 宮川和 明*5, 村上行夫*6 \\ Takuya UEKI, Haruyuki KITAMURA, Toshiaki SATO, \\ Daiki SATO, Kazuaki MIYAGAWA and Yukio MURAKAMI
}

\begin{abstract}
This paper discusses about the difference of damage degree calculated by Miner's rule and by energy evaluation method. The dynamic loading tests for the buckling restrained brace is carried out by exchanging the input order of large and small amplitudes considered to be the cause of the dispersion. As a result, it is confirmed that the damage degree calculated by energy evaluation method is estimated to be small by about $15 \%$ when receiving large deformation first. Furthermore, It is found that the damage degree by the average amplitude method using the cumulative average strain amplitude is evaluated to be small compared with the case using the logarithmic mean strain amplitude.
\end{abstract}

Keywords : Damage degree, Miner's rule, Average amplitude method, Buckling restrained brace 損傷度, マイナー則, 平均振幅則, 座屈拘束ブレース

\section{1. はじめに}

2011 年 3 月に発生した東北地方太平洋沖地震を受け,国や自治体 において想定地震の見直しが進められるとともに例えば1),2), 大規模地 震発生後も建物の継続利用を可能とする高耐震性要求が広まりつつ ある。これに対し，地震エネルギーを集中的に制振ダンパーで吸収 し，主架構の損傷を抑制する損傷制御設計の考え方が重要度を増し ている。また，地震被災後の制振ダンパーの損傷状態を適切に判断 し, 復旧寸ることで, 粘り強く継続性の高い建物の実現が可能と考 えられる。一方で, 制振ダンパーの一つである座屈拘束ブレースは, 塑性化部が補剛材に覆われているため，内部の損傷状態を視覚的に 把握することが難しく，継続使用の可否判断は，観測波形あるいは 想定地震動を用いた解析的手法に頼らざるをえないのが現状である。

塑性化領域を含むランダム応答に対する損傷度評価法としては, 振幅情報のみから推定する Miner 則評価法と, エネルギー吸収量を 指標としたエネルギー評価法の大きく二つが挙げられる。

Miner 則は，変位振幅のランダム応答波形を一定振幅とみなせる 波形に分解し, 疲労曲線式を用いて算定される個々の波形に対寸る 損傷度を逐次足し合わせていく方法である。Miner 則に関する既往 の研究は多く，例えば，ダンパー用鋼材である低降伏点鋼に適用し た瀬戸ら ${ }^{3)}$ の研究, 構造形式の異なる座屈拘束ブレースに適用した
小野ら 4)，寺田ら5)の研究などがある。Miner 則評価による推定損 傷度は, ばらつきはあるものの, 概㸚実験結果における損傷状態と 良い一致を示すことが確認されている。

エネルギー評価法の一つとして, ランダム応答波形を, 最大振幅 で一定かつエネルギー吸収量が等価となる一定振幅波形に置き換え て, 得られた等価繰返しサイクル数から損傷度を算定する最大振幅 則がある。小山ら ${ }^{6)}$ は, 低降伏点鋼を用いた耐力パネルに最大振幅 則を採用した結果, 確実に安全側の評価を与えるものの, 最大塑性 変形が小さい場合は安全率が過大となることを示している。また, 竹内ら 7) は, 座屈拘束ブレースの載荷履歴を骨格部とバウシンガー 部に分解し，破断に至るまでの累積塑性エネルギーを予測すること で，損傷度を推定する手法を提案している。

現行の設計においては, 2014 年に発行された鋼構造制振設計指針 8)に基づき, ダンパー形状の差異や地震応答解析結果のばらつき, 過去に受けた損傷の蓄積や余震時の損傷などを考慮した適切な安全 率を設定した上で, Miner 則を用いた損傷度評価を採用するケース が多いと考えられる。一方で, エネルギ一評価法は, 波形分解や逐 次計算といった手間を省略できることから実用上簡便であり, 累積 塑性変形倍率を予測可能なエネルギー法を用いた耐震設計 9)への適 用を鑑みれば，有用な手法と言える。

\footnotetext{
*1 JFE スチール(株)スチール研究所 課長・修士 (工学)

*2 東京理科大学理工学部建築学科 教授. 博士 (工学)

*3 九州大学大学院人間環境学研究院 准教授·博士 (工学)

*4 東京工業大学未来産業技術研究所 准教授 - 博士 (工学)

* $5 \mathrm{JFE}$ シビル(株) 部長・博士 (工学)

*6 JFE スチール(株) 副部長・修士 (工学)
}

\author{
Manager, Steel Research Laboratory, JFE Steel Corp., M. Eng. \\ Prof., Dept. of Architecture, Tokyo Univ. of Science, Dr. Eng. \\ Assoc. Prof., Faculty of Human-Environment Studies, Kyushu Univ., Dr. Eng. \\ Assoc. Prof., FIRST, Tokyo Inst. of Technology, Dr. Eng. \\ General Manager, JFE Civil Engineering \& Constraction Corp., Dr. Eng. \\ Deputy General Manager, JFE Steel Corp., M. Eng.
}


筆者らは, Miner 則とほぼ同等の評価が可能となるエネルギー評 価法の構築を目指し, ランダム応答波形を波形分解して得られる半 サイクルごとのひずみ振幅の単純累加平均で算定される累加平均ひ ずみ振幅を用いた平均振幅則を提案してきた ${ }^{10), 11)}$ 。結果として, 最 大振幅則と比べて Miner 則評価に近い損傷度を推定できるものの， 危険側の評価を与える可能性もあることが確認された。

そこで本論文では，低降伏点鋼を用いた十字型断面の軸材と，溶 接組立箱形断面の補剛材で構成される座屈拘束ブレースを対象に, 軸材の塑性化部長さを短くし, 補剛材の板厚を十分厚くすることで 座屈拘束力の影響を極力排除した基本モデル試験体と，実大サイズ 試験体による動的載荷実験を実施した。基本モデル試験体では，一 定振幅載荷実験により疲労曲線式を求めた後，大・小の振幅を組み 合わせて入力順序を入れ替えた多段振幅載荷実験と，地震応答波形 とそれの時間軸のみを反転させた波形による地震動加力実験を実施 した。実大サイズ試験体では, 一定振幅載荷実験により改めて疲労 曲線式を設定した後, 基本モデル実験で確認された大・小振幅の入 力順序による損傷度影響について確認するため, 大・小 2 段階のひ ずみ振幅を交互に繰り返す連続 2 段振幅載荷実験と, 入力振幅の大 きさのみが異なる地震応答波形の入力順序を入れ替えた地震動加力 実験を行った。さらに, FEM 解析を用いて, 入力順序の違いが座 屈拘束ブレースのひずみ挙動に及ぼす影響を詳細に分析した。

これらの実験および解析結果から, Miner 則評価による損傷度に 対する平均振幅則による損傷度の比を比較することで, 変位振幅の 入力順序が平均振幅則による損傷度に与える影響を定量的に評価す る。また, 新たに提案する疲労曲線式の勾配 $\beta$ に基づく対数平均ひ ずみ振幅と, 累加平均ひずみ振幅を用いた平均振幅則による損傷度 の比を比較することにより, 平均ひずみ振幅の与え方の違いが平均 振幅則の損傷度評価に与える影響を評価する。

\section{2. 対象とする座屈拘束ブレースと損傷度評価法}

\section{1 座屈拘束ブレースの構造}

本論文で評価対象とする座屈拘束ブレースは，Fig.1 に示すよう に，低降伏点鋼を用いた十字型断面の軸材と，溶接組立箱形断面の 補剛材で構成される。補剛材の対角方向に軸材を配置することで, 主軸材縁端部の面外変形を補剛材隅角部で拘束し, 幅厚比の小さい 副軸材の補剛効果で主軸材中央部の局部変形を抑制する機構を有す る。補剛材隅角部には，潤滑剤を塗布したライナープレートが全長 に亘り挿入されており, 摩擦による補剛材一の軸力伝達を抑制して いる。軸材と補剛材とのクリアランスは, 軸材板厚の $1 / 10$ 以下とす ることで性能に影響が生じないことを確認している。また，主架構 とのボルト接合部を含む端部材は，軸材のひずみ硬化による応力上 昇に対しても弾性内にとどまるように，軸材とは異なる強度の材料 を用いている。さらに, 全体座屈を防止するために端部材の一部が 補剛材内に挿入され，軸材と完全溶け込み溶接にて接合される。

\section{2 損傷度算定式の定義}

本論文で採用する Miner 則と平均振幅則による損傷度算定式を 以下のように定義する。

I . Miner 則評価（振幅評価）

はじめに, 評価対象とする座屈拘束ブレースと同形状の試験体を 用いた一定振幅載荷実験により疲労曲線式を設定する。軸材塑性化

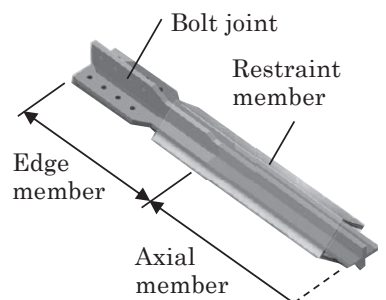

(a)Perspective Vièw

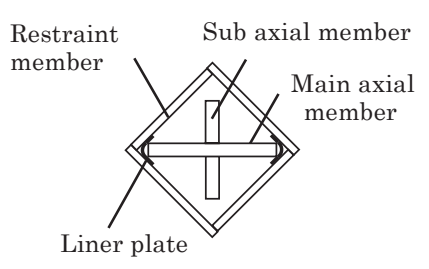

(b)Section View
Fig.1 Configuration of buckling restrained brace

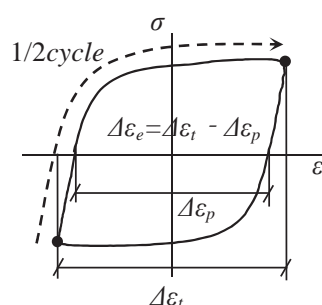

Fig.2 Definition of strain amplitude

部のひずみ振幅を Fig.2 のように定義すると，全ひずみ振幅 $\Delta \varepsilon_{\mathrm{t}}$ と 限界繰返しサイクル数 $\mathrm{N}_{\mathrm{cr}}$ の関係は, 弾性ひずみ振幅 $\Delta \varepsilon_{\mathrm{e}}$ と塑性ひ ずみ振幅 $\Delta \varepsilon_{\mathrm{p}}$ の足し合わせとして, Manson-Coffin 則 12),13)に従う下 式で表現できる。

$$
\Delta \varepsilon_{\mathrm{t}}=\Delta \varepsilon_{\mathrm{e}}+\Delta \varepsilon_{\mathrm{p}}=\mathrm{C}_{1} \cdot\left(\mathrm{N}_{\mathrm{cr}}\right)^{-\beta_{1}}+\mathrm{C}_{2} \cdot\left(\mathrm{N}_{\mathrm{cr}}\right)^{-\beta_{2}}
$$

ここに, $\mathrm{C}_{1}, \mathrm{C}_{2}, \beta_{1}, \beta_{2}$ は, 一定振幅載荷実験から求まる定数である。 一方で, 制振ダンパーである座屈拘束ブレースは, 弾性ひずみと比 較して塑性ひずみが支配的となることから，本論文では，簡易的に 全ひずみ振幅 $\Delta \varepsilon_{\mathrm{t}}$ を用いた以下の回帰式 8)を用いることとする。

$$
\Delta \varepsilon_{\mathrm{t}}=\mathrm{C} \cdot\left(\mathrm{N}_{\mathrm{cr}}\right)^{-\beta}
$$

ここに, $\mathrm{C}, \beta$ は, 一定振幅載荷実験から求まる定数である。

次に, 座屈拘束ブレースの軸材塑性化部に生じるランダム応答ひ ずみ波形を，一定振幅とみなせる半サイクルに分解する。波形分解 には，極大值一極小值間を全ひずみ振幅とする極值法 10)を用いる。 得られた $\mathrm{i}$ 番目の半サイクルに対する損傷度 $D_{i}$ を逐次足し合わせ ることで，Miner 則評価による損傷度 $\mathrm{D}_{\mathrm{m}}$ は下式で算定できる。

$$
D_{m}=\sum_{i=1}^{n} \frac{1 / 2}{i} N_{c r}=\frac{1}{2} \cdot \sum_{i=1}^{n}\left(\frac{\Delta_{i} \varepsilon_{t}}{C}\right)^{1 / \beta}
$$

ここに, $\mathrm{n}$ : 波形分解で得られた半サイクル数, $\mathrm{i} \mathrm{N}_{\mathrm{cr}}$ : $\mathrm{i}$ 番目の全 ひずみ振幅 $\Delta_{i} \varepsilon_{\mathrm{t}}$ に対する限界繰返しサイクル数である。なお, 分解 された波形のうち，全ひずみ振幅が弾性範囲内 $\left(\Delta \varepsilon_{\mathrm{t}} \leqq \Delta \varepsilon_{\mathrm{y}}=2 \varepsilon_{\mathrm{y}}\right.$ ， $\varepsilon_{\mathrm{y}}$ : 降伏ひずみ) の波形は，損傷度への影響が小さいものとして除 外している。

II . 平均振幅則評価（エネルギー評価）

ランダム応答波形を，総エネルギー吸収量W が等価で，かつ全ひ ずみ振幅の平均值 $\Delta_{\mathrm{eq}} \varepsilon_{\mathrm{t}}$ で一定となる波形に置き換えると，等価な 繰返しサイクル数 $\mathrm{N}_{\mathrm{eq}}$ は下式で表現できる。

$$
\mathrm{N}_{\text {eq }}=\frac{\mathrm{W}}{{ }_{\mathrm{eq}} \mathrm{W}_{1}}
$$

ここに, ${ }_{\mathrm{eq}} \mathrm{W}_{1}$ は $\Delta_{\mathrm{eq}} \varepsilon_{\mathrm{t}}$ に対する 1 サイクルあたりのエネルギー吸収 
量である。W， eq $W_{1}$ はいずれも降伏応力度 $\sigma_{\mathrm{y}}$ と降伏ひずみ $\varepsilon_{\mathrm{y}}$ で除 すことにより, 累積塑性変形倍率の形に置き換えることができる。

$$
\eta=\frac{W}{\sigma_{\mathrm{y}} \cdot \varepsilon_{\mathrm{y}}} \quad \text { (5) } \quad \quad \eta_{1}=\frac{{ }_{\mathrm{eq}} \mathrm{W}_{1}}{\sigma_{\mathrm{y}} \cdot \varepsilon_{\mathrm{y}}}
$$

ここに, $\eta$ は継続時間における総累積塑性変形倍率, eq $\eta_{1}$ は $\Delta_{\mathrm{eq}} \varepsilon_{\mathrm{t}}$ に 対する 1 サイクルあたりの累積塑性変形倍率である。ある全ひずみ 振幅 $\Delta_{\mathrm{i}} \varepsilon_{\mathrm{t}}$ に対する 1 サイクルあたりの累積塑性変形倍率 ${ }_{\mathrm{i}} \eta_{1}$ は, 一 定振幅載荷実験結果による限界累積塑性変形倍率 ${ }_{\mathrm{i}} \eta_{\mathrm{cr}}$ と限界繰返し サイクル数 $\mathrm{N}_{\mathrm{cr}}$ を用いた平均累積塑性変形倍率, $\bar{\eta}_{1}$ として下式で定 義する。

$$
{ }_{i} \eta_{1}={ }_{i} \bar{\eta}_{1}=\frac{{ }_{i} \eta_{\mathrm{cr}}}{{ }_{i} \mathrm{~N}_{\mathrm{cr}}}
$$

よって, 平均振幅則による損傷度 $\mathrm{D}_{\mathrm{e}}$ は下式で算定できる。

$$
\mathrm{D}_{\mathrm{e}}=\frac{\mathrm{N}_{\text {eq }}}{{ }_{\text {eq }} \mathrm{N}_{\text {cr }}}=\frac{\mathrm{W} /{ }_{\text {eq }} \mathrm{W}_{1}}{{ }_{\text {eq }} \mathrm{N}_{\mathrm{cr}}}=\frac{\eta / \text { eq }}{\bar{\eta}_{1}}
$$

ここに, eq $\mathrm{N}_{\mathrm{cr}}$ は $\Delta_{\mathrm{eq}} \varepsilon_{\mathrm{t}}$ に対する限界繰返しサイクル数である。

ここで，全ひずみ振幅の平均值 $\Delta_{\mathrm{eq}} \varepsilon_{\mathrm{t}}$ を二つの手法で設定する。 一つは, Miner 則における損傷度 $D_{m}$ を, 波形分解された半サイク ル数 $\mathrm{n}$ で平均化して得られる平均ひずみ振幅 $\Delta_{\mathrm{eq} 1} \mathcal{E}_{\mathrm{t}}$ であり, 式(3)を 用いて，以下のように定義する。

$$
\begin{aligned}
& \frac{D_{m}}{n}=\frac{1}{2 n} \cdot \sum_{i=1}^{n}\left(\frac{\Delta_{i} \varepsilon_{t}}{C}\right)^{1 / \beta}=\frac{1}{2} \cdot\left(\frac{\Delta_{\text {eq } 1} \varepsilon_{t}}{C}\right)^{1 / \beta} \\
& \therefore \Delta_{\text {eq } 1} \varepsilon_{t}=\left\{\frac{1}{n} \cdot \sum_{i=1}^{n}\left(\Delta_{i} \varepsilon_{t}\right)^{1 / \beta}\right\}^{\beta}
\end{aligned}
$$

この平均ひずみ振幅 $\Delta_{\mathrm{eq} 1} \varepsilon_{\mathrm{t}}$ は, 疲労曲線式の勾配 $\beta$ に基づき対数 平均されたひずみ振幅（以降, 対数平均ひずみ振幅と称する）であ り, Miner 則における平均ひずみ振幅と同義である。

もう一つは, 計算が簡便な平均ひずみ振幅として, 波形分解され た半サイクルごとのひずみ振幅の単純累加平均で算定される平均ひ ずみ振幅（以降，累加平均ひずみ振幅と称す） $\Delta_{\mathrm{eq} 2} \varepsilon_{\mathrm{t}}$ であり，下式 で定義する。

$$
\Delta_{\mathrm{eq} 2} \varepsilon_{\mathrm{t}}=\frac{1}{\mathrm{n}} \cdot \sum_{\mathrm{i}=1}^{\mathrm{n}} \Delta_{\mathrm{i}} \varepsilon_{\mathrm{t}}
$$

式(10)と式(11)を比較すると, 一定振幅波形に対しては $\beta$ によら ず $\Delta_{\mathrm{eq} 1} \varepsilon_{\mathrm{t}}=\Delta_{\mathrm{eq} 2} \varepsilon_{\mathrm{t}}$ となり， $\beta=1.0$ のときはランダム波形に含まれる ひずみ振幅によらず $\Delta_{\mathrm{eq} 1} \varepsilon_{\mathrm{t}}=\Delta_{\mathrm{eq} 2} \varepsilon_{\mathrm{t}}$ となることが分かる。対数平均ひ ずみ振幅 $\Delta_{\mathrm{eq} 1} \varepsilon_{\mathrm{t}}$ と累加平均ひずみ振幅 $\Delta_{\mathrm{eq} 2} \varepsilon_{\mathrm{t}}$ を用いて, 平均振幅則 で算定した損傷度をそれぞれ $\mathrm{D}_{\mathrm{e} 1}, \mathrm{D}_{\mathrm{e} 2}$ とすると, 式(8)と同様に下式 で表現できる。

$$
\mathrm{D}_{\mathrm{e} 1}=\frac{\eta / \text { eq } 1 \bar{\eta}_{1}}{\text { eq } 1_{\mathrm{cr}}} \quad \text { (12) } \quad \mathrm{D}_{\mathrm{e} 2}=\frac{\eta / \text { eq } 2 \bar{\eta}_{1}}{\text { eq } 2_{\mathrm{cr}}}
$$

以上のようにして，3 つの手法による損傷度 $\left(D_{\mathrm{m}}, \mathrm{D}_{\mathrm{e} 1}, \mathrm{D}_{\mathrm{e} 2}\right)$ を 定義した。同じ刘数平均ひずみ振幅 $\Delta_{\mathrm{eq} 1} \mathcal{E}_{\mathrm{t}}$ を用いて, Miner 則によ る損傷度 $\mathrm{D}_{\mathrm{m}}$ に対する平均振幅則による損傷度 $\mathrm{D}_{\mathrm{e} 1}$ の比を比較する ことで, 変位振幅の入力順序が平均振幅則評価に与える影響をエネ ルギー吸収の視点から考察する。また, 同じ平均振幅則に対して, 対数平均ひずみ振幅 $\Delta_{\mathrm{eq} 1} \varepsilon_{\mathrm{t}}$ を用いた損傷度 $\mathrm{D}_{\mathrm{e} 1}$ に対する累加平均ひ ずみ振幅 $\Delta_{\mathrm{eq} 2} \varepsilon_{\mathrm{t}}$ を用いた損傷度 $\mathrm{D}_{\mathrm{e} 2}$ の比を比較することで, 平均ひ ずみ振幅の与え方の違いが平均振幅則評価に与える影響を考察する。

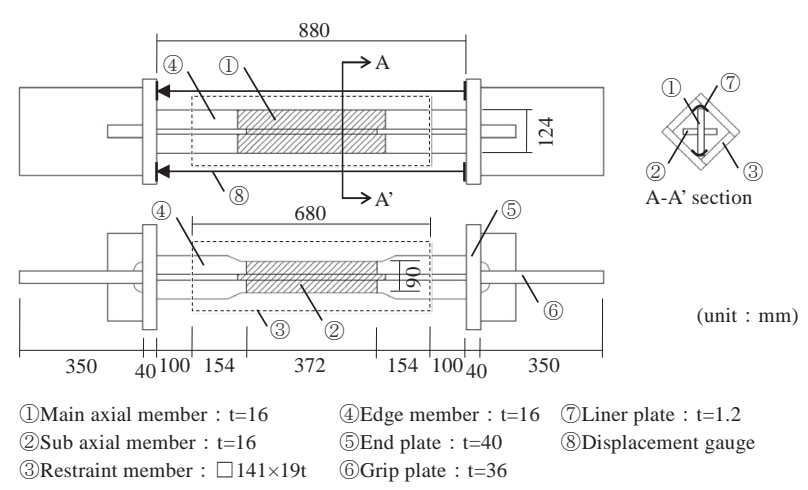

Fig.3 Shape of specimen (Basic model size)

Table1 Results of material testing (Basic model size)

\begin{tabular}{c|c|c|c|c|c|c}
\hline Member & M aterial & $\begin{array}{c}\text { Thickness } \\
(\mathrm{mm})\end{array}$ & $\begin{array}{c}\text { Y ield } \\
\text { Strength } \\
\left(\mathrm{N} / \mathrm{mm}^{2}\right)\end{array}$ & $\begin{array}{c}\text { Tensile } \\
\text { Strength } \\
\left(\mathrm{N} / \mathrm{mm}^{2}\right)\end{array}$ & $\begin{array}{c}\text { Y ield } \\
\text { Ratio } \\
(\%)\end{array}$ & $\begin{array}{c}\text { Elongation } \\
(\%)\end{array}$ \\
\hline A xial & LY 225 & 16.0 & 208.9 & 310.5 & 67.3 & 61.3 \\
\hline Edge & SN 490B & 16.0 & 345.1 & 520.5 & 66.3 & 28.3 \\
\hline Restraint & SM 490A & 19.1 & 370.6 & 520.9 & 71.2 & 27.4 \\
\hline
\end{tabular}

\section{3. 基本性能確認実験}

\section{1 試験体}

大・小振幅の入力順序による影響を確認するにあたり，ばらつき 要因の一つとして考えられる座屈拘束力の影響を極力排除するため, 軸材の塑性化部長さを短くし, 補剛材の板厚を十分厚くした基本モ デル試験体による多段振幅載荷実験および動的載荷実験を実施した。 試験体形状を Fig. 3 に，素材試験結果をTable1 に示す。

\section{2 一定振幅載荷実験}

はじめに, Fig.3の試験体を用いた一定振幅載荷実験（F1～F4） により疲労曲線式を求めた後, $\Delta \varepsilon_{\mathrm{t}}=1.0 \%, 2.0 \%, 3.0 \%$ の振幅を組み 合わせて入力順序を入れ替えた多段振幅載荷実験（F5～F12）を行 った。載荷装置を Fig. 4 に, 載荷パラメータを Table2 に示す。

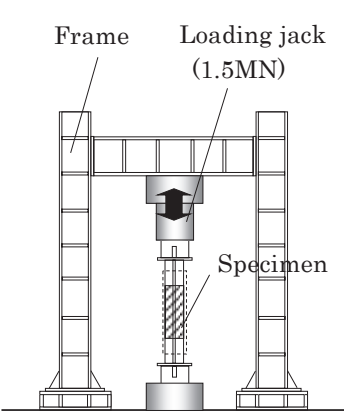

Fig.4 Loading system

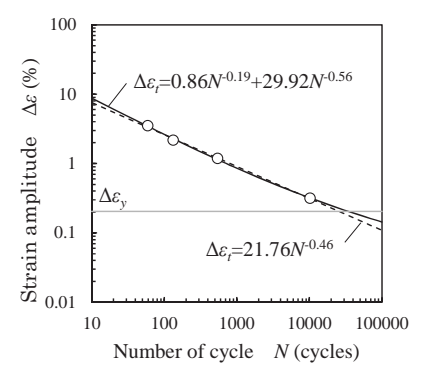

Fig.5 $\Delta \varepsilon_{t}-N_{c r}$ relationship

\begin{tabular}{c|c|c}
\multicolumn{3}{c}{ Table2 Loading pattern } \\
\hline $\begin{array}{c}\text { Test } \\
\text { Body }\end{array}$ & Loading & $\begin{array}{c}\text { Pattern } \\
\text { F }\end{array}$ \\
\hline F1 & & $(\%)$ \\
F2 & Constant & 0.3 \\
F3 & A mplitude & 1.0 \\
F4 & & 2.0 \\
\hline F5 & & 3.0 \\
F6 & & $1.0 \rightarrow 2.0$ \\
F7 & & $2.0 \rightarrow 1.0$ \\
F8 & M ultistage & $1.0 \rightarrow 3.0$ \\
F9 & A mplitude & $3.0 \rightarrow 1.0$ \\
F10 & & $1.0 \rightarrow 2.0 \rightarrow 3.0$ \\
F11 & & $3.0 \rightarrow 2.0 \rightarrow 1.0$ \\
F12 & & $1.0 \rightarrow 2.0 \rightarrow 3.0 \rightarrow 2.0 \rightarrow 1.0$ \\
& & $3.0 \rightarrow 2.0 \rightarrow 1.0 \rightarrow 2.0 \rightarrow 3.0$ \\
\hline
\end{tabular}

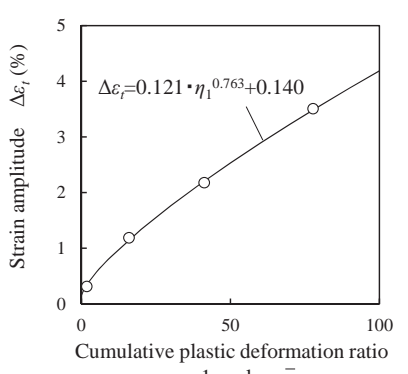

per 1 cycle $\bar{\eta}_{1}$

Fig.6 $\Delta \varepsilon_{t}-\bar{\eta}_{1}$ relationship 
ここで，以降に示寸全ての実験において，載荷は端部材を含めた 全体長さの変位振幅で制御し, 地震動を用いたランダム載荷を除き, 縮小試験体は最大ひずみ速度が約 3.0\%/sec の正弦波による動的載 荷，実大試験体はひずみ速度が約 $0.03 \% / \mathrm{sec}$ で一定となる三角波の 静的載荷とした。また，軸材塑性化部のひずみは，変位計による全 体変形から端部材の弾性変形計算量を差し引き, 塑性化部長さで除 すことで算定している。疲労限界は，破断あるいは最大耐力の約 85\%まで低下のいずれか先に達した時点とした。

一定振幅載荷実験で得られた全ひずみ振幅 $\Delta \varepsilon_{\mathrm{t}}$ と限界繰返しサイ クル数 $\mathrm{N}_{\mathrm{cr}}$ の関係 (プロット), および式(1), 式(2)の回帰式を Fig. 5 に示す。ここに, 式(1)の定数は $C_{1}=0.86, C_{2}=29.92, \beta_{1}=0.19, \beta_{2}=$ 0.56, 式(2)の定数は $C=21.76, \beta=0.46$ とした。2.2 節で述べたよう に, 塑性ひずみが支配的となる高ひずみ範囲 $\left(\Delta \mathcal{E}_{\mathrm{t}}\right.$ 約 $\left.4.0 \%\right)$ では, 式(1), 式(2) および実験結果はよい一致を示している。一方で, 弾 性ひずみが支配的となる低ひずみ範囲では式(1)と式(2)に乘離がみ られるものの, $\Delta \varepsilon_{\mathrm{t}} \geqq \Delta \varepsilon_{\mathrm{y}}$ では概ね一致しており， $\Delta \varepsilon_{\mathrm{y}} \leqq \Delta \varepsilon_{\mathrm{t}} \leqq$ 約 $4.0 \%$ 範囲において, 式(2)を適用することは問題ないと言える。

また，エネルギー評価法で必要となる 1 サイクルあたりの平均累 積塑性変形倍率 $\bar{\eta}_{1}$ と全ひずみ振幅 $\Delta \mathcal{E}_{\mathrm{t}}$ の関係（プロット）を Fig.6 に示す。ここで， $\bar{\eta}_{1}$ と全ひずみ振幅 $\Delta \varepsilon_{\mathrm{t}}$ の関係を定式化するにあた り, $\bar{\eta}_{1}$ と塑性ひずみ振幅 $\Delta \varepsilon_{\mathrm{p}}$ の関係, および $\Delta \varepsilon_{\mathrm{t}}$ と $\Delta \varepsilon_{\mathrm{p}}$ の関係をそ れぞれ個別に評価したところ，下式で回帰できることが分かった。

$$
\Delta \varepsilon_{\mathrm{p}}=0.111 \cdot \bar{\eta}_{1}^{0.763} \quad(14) \quad \Delta \varepsilon_{\mathrm{t}}=1.086 \cdot \Delta \varepsilon_{\mathrm{p}}+0.140
$$

そこで，式(14)と式(15)を用いて， $\bar{\eta}_{1}$ と $\Delta \varepsilon_{\mathrm{t}}$ の関係を以下のように 定式化した。

$$
\Delta \varepsilon_{\mathrm{t}}=0.121 \cdot \bar{\eta}_{1}^{0.763}+0.140
$$

式(16)の回帰式を Fig.6 中に併せて示す。回帰式は実施した一定振 幅載荷実験の範囲において, プロットと良い一致を示している。

\section{3 多段振幅載荷実験}

次に, 前述の疲労曲線式を用いて推定される Miner 則の損傷度か ら，多段振幅載荷実験における各ひずみレベルでの目標繰返しサイ クル数を設定した。具体的には, Table3 に示すように, 載荷終了時 に推定損傷度が 1.0 となり，かつ各ひずみ振幅レベルでの損傷度が 等分となるように設定した。

多段振幅載荷実験における軸材塑性化部の応力ーひずみ関係を Fig.7 に示す。なお，基本モデル試験体を用いた実験においては， 正側を圧縮とし, 載荷サイクル数の多いものは代表值を示している。 ここで, 振幅の入力順序のみを入れ替えたペアとなる試験体は，目 標と寸る載荷振幅およびサイクル数が一致する計画としていたが， 実際には試駼機の制御能力の関係で入力振幅にばらつきが生じたた め, 入力振幅に応じて都度サイクル数を調整しながら載荷を行った。 特に F8 試験体は，振幅調整がうまくいかず，目標の全ひずみ振幅 に対して 6 割程度となっている。

先に小振幅を受けた試験体（F5,F9）と先に大振幅を受けた試験 体（F6,F10）を比較すると，大振幅の復元力特性は，F6,F10 では 安定した紡錘形の履歴を描いている。一方で，F5,F9 では，ひずみ がゼロとなる近傍で剛性・耐力の低下が見られ，その後，最大ひず みに向かって徐々に剛性・耐力が回復する履歴となっている。また， 小振幅の復元力特性は, F6,F10 において大振幅後の応力低下が大 きい傾向が認められる。また, 大・小振幅を増減させた F11,F12 試
Table3 Target number of cycle

\begin{tabular}{c|c|c|l}
\hline No. & \multicolumn{1}{|c|}{$\begin{array}{c}\text { Loading pattern } \\
\Delta \varepsilon_{\mathrm{t}}(\%)\end{array}$} & \multicolumn{1}{c|}{$\begin{array}{c}\text { Target damage index } \\
\mathrm{D}_{\mathrm{m}}\end{array}$} & \multicolumn{1}{c}{$\begin{array}{c}\text { Target number of cycle } \\
\mathrm{N} \text { (cycles) }\end{array}$} \\
\hline F5 & $1.0 \rightarrow 2.0$ & $0.50 \rightarrow 0.50$ & $405 \rightarrow 90$ \\
F6 & $2.0 \rightarrow 1.0$ & $0.50 \rightarrow 0.50$ & $90 \rightarrow 405$ \\
F7 & $1.0 \rightarrow 3.0$ & $0.50 \rightarrow 0.50$ & $405 \rightarrow 37$ \\
F8 & $3.0 \rightarrow 1.0$ & $0.50 \rightarrow 0.50$ & $37 \rightarrow 405$ \\
F9 & $1.0 \rightarrow 2.0 \rightarrow 3.0$ & $0.33 \rightarrow 0.33 \rightarrow 0.33$ & $270 \rightarrow 60 \rightarrow 25$ \\
F10 & $3.0 \rightarrow 2.0 \rightarrow 1.0$ & $0.33 \rightarrow 0.33 \rightarrow 0.33$ & $25 \rightarrow 60 \rightarrow 270$ \\
F11 & $1.0 \rightarrow 2.0 \rightarrow 3.0 \rightarrow 2.0 \rightarrow 1.0$ & $0.17 \rightarrow 0.17 \rightarrow 0.33 \rightarrow 0.17 \rightarrow 0.17$ & $135 \rightarrow 30 \rightarrow 25 \rightarrow 30 \rightarrow 135$ \\
F12 & $3.0 \rightarrow 2.0 \rightarrow 1.0 \rightarrow 2.0 \rightarrow 3.0$ & $0.17 \rightarrow 0.17 \rightarrow 0.33 \rightarrow 0.17 \rightarrow 0.17$ & $12 \rightarrow 30 \rightarrow 270 \rightarrow 30 \rightarrow 12$ \\
\hline
\end{tabular}
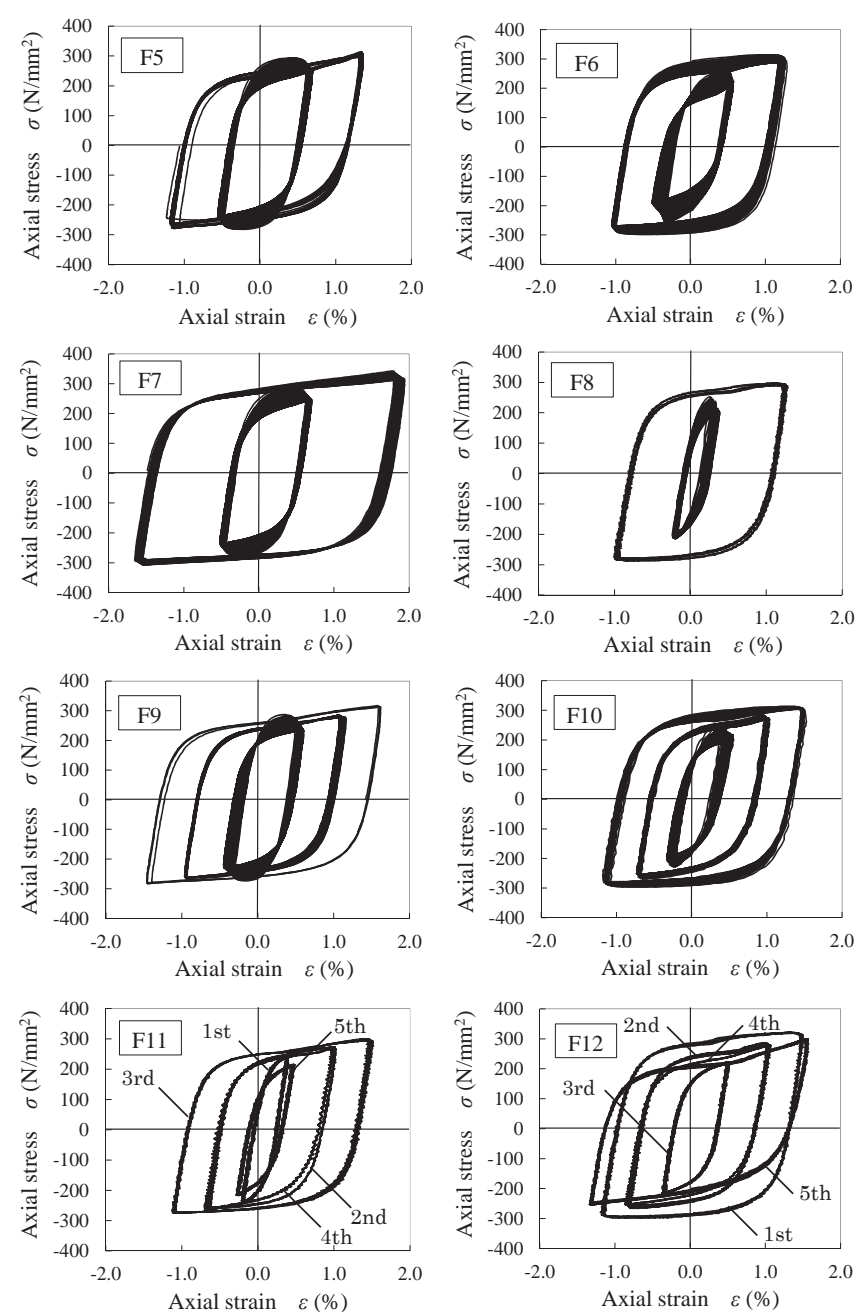

Fig.7 $\sigma-\varepsilon$ relationship (Multi-stage amplitude)
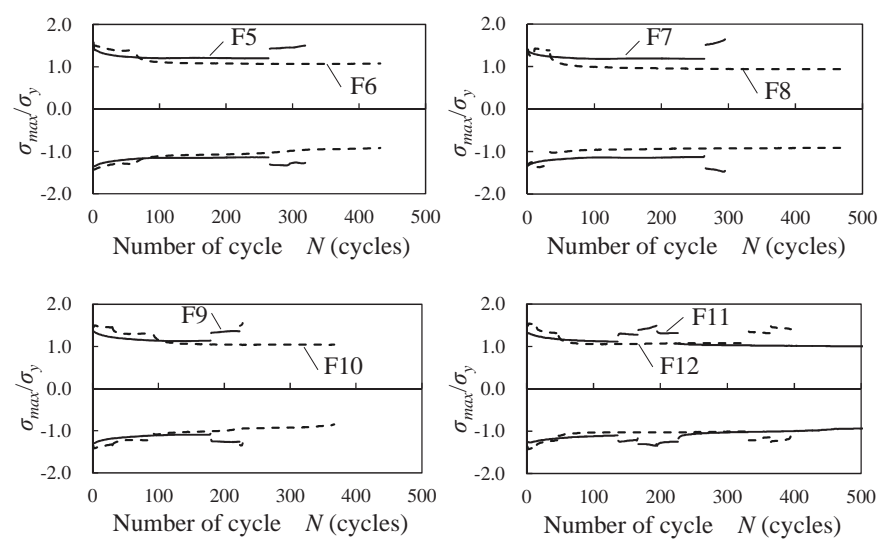

Fig.8 Progress of $\sigma_{\max } / \sigma_{y} \quad$ (Multi-stage amplitude) 
験体に着目すると, 同じひずみ振幅であっても最初の載荷時よりも， 多段振幅を受けた後の載荷時の履歴面積が小さくなっており, 特に, 先に大振幅を受けた F12 試験体では, その差が大きく表れている。 繰返しサイクルごとに, 最大応力を降伏応力で基準化した応力上昇 率の推移を Fig. 8 に示す。振幅の大 ・小によらず, 載荷初期の応力 上昇率はほぼ近い值となっているが，先に大振幅を受けた F6,F8, F10 では, 小振幅時の応力上昇率が F5,F7,F9 と比較して低くなっ ている。一方で, F11 と F12 で大振幅を受けた後の小振幅時におけ る応力上昇率を比較すると, 大きな差は見られない。

これらの大 ・ 小振幅の入力順序による復元力特性の変化や応力低 下の要因については，5 章で改めて考察する。

\section{4 時間軸反転載荷実験}

次に, 地震時のランダム応答波形に対する載荷振幅の入力順序に よる影響を評価するため, 波形に含まれるひずみ振幅の成分が同じ で，時間軸のみを反転させた地震動加力実験を実施した。試験体は Fig. 3 と同じ仕様とし, Fig.9 に示寸載荷装置を用いた。実験に先立 ち, 座屈拘束ブレースを組み込んだ試設計建物（40 層純ラーメン鉄 骨造建物）に，南海地震に対する大阪での想定地震波（OSA NS） を入力した時刻歷応答解析 10 )を実施し, 層間変形角が最大となった 7 層部分のブレース軸方向応答波形を抽出した。解析で得られた応 答波形をそのまま試験体に入力（正方向入力）した場合と，時間軸 を反転させた波形を入力（逆方向入力）した場合の，座屈拘束ブレ

ースに生じた軸ひずみ応答波形を Fig.10に示す。

正方向入力では, 10 回の入力に対しても耐力低下が見られなかっ たことから，入力波形の振幅を 1.5 倍に拡大して載荷を継続したと ころ, 10 回目の入力で軸材の破断に至った。逆方向入力では, 同様 に原波を 10 回入力後, 1.5 倍に拡大した波形の 13 回目の入力で最

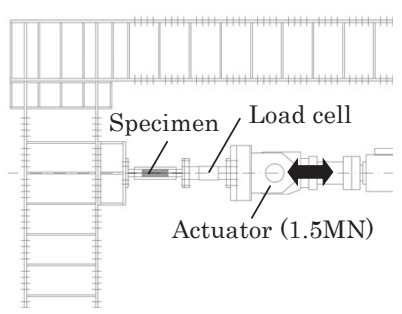

Fig.9 Loading system

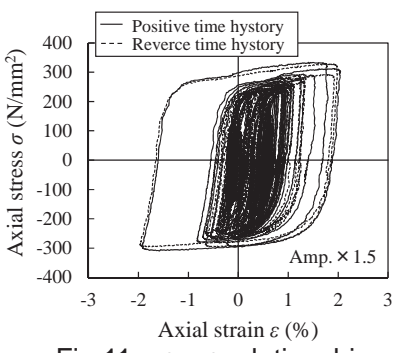

Fig.11 $\sigma-\varepsilon$ relationship
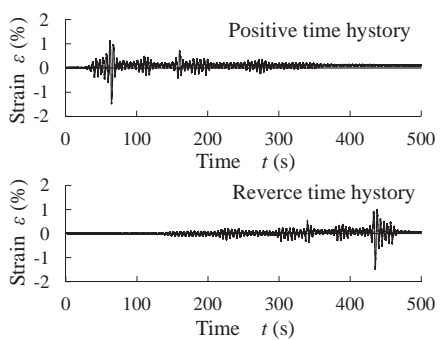

Fig.10 Response strain wave

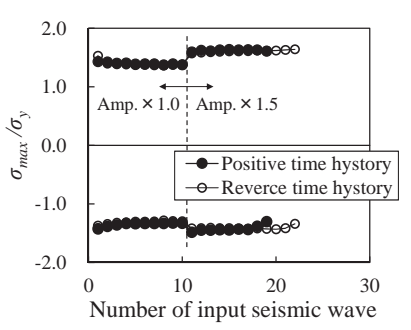

Fig.12 Progress of $\sigma_{\max } / \sigma_{y}$

Table4 Result of damage index for basic model

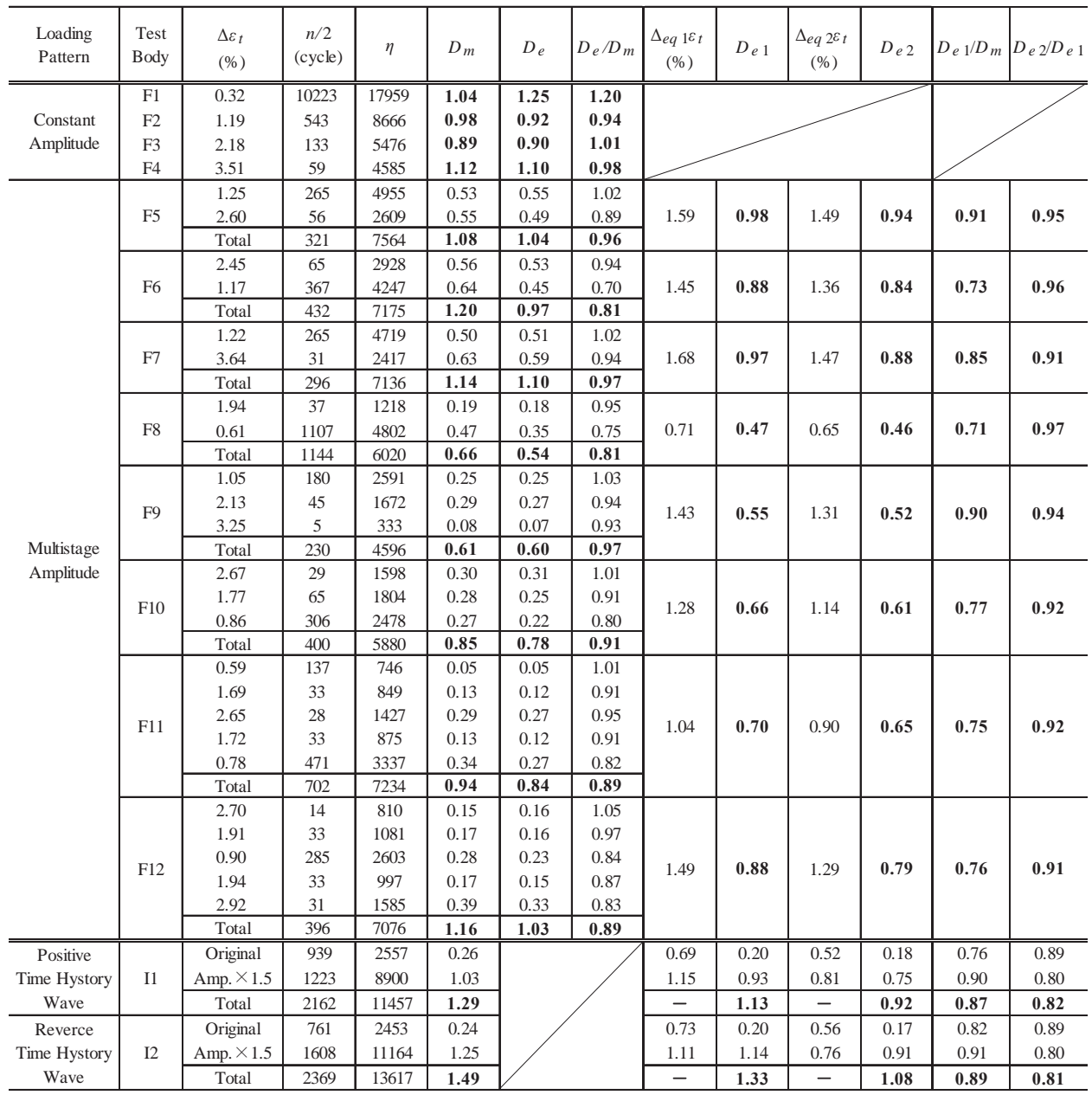

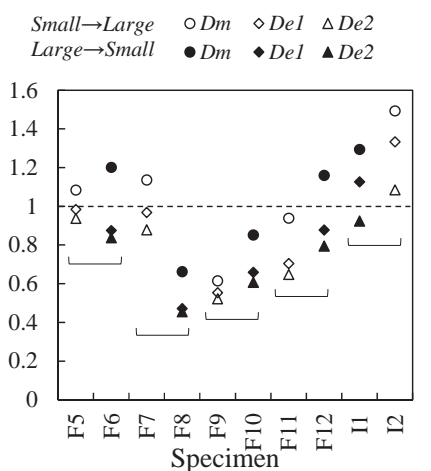

Fig.13 Comparison of $D$

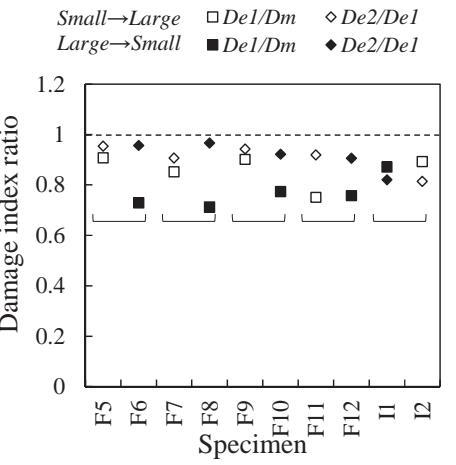

Fig.14 Comparison of $D$ ratio 
大耐力の $85 \%$ 以下に低下し, 疲労限界に至った。疲労限界に差が生 じたものの, Fig. 11 に示寸復元力特性（入力振幅 $\times 1.5$ 倍），および Fig.12 に示寸降伏応力で基準化した最大応力の推移ともに, 時間軸 の入力方向の違いによる差は見られなかった。

\section{5 損傷度評価結果}

前述の各実験結果に対し， 2.2 節で定義した Miner 則と平均振幅 則を用いて算定した損傷度結果を Table4 および Fig.13 に示す。 Miner 則評価による損傷度 $\mathrm{D}_{\mathrm{m}}$ は約 $0.6 \sim 1.5$ の間でばらついており, この傾向は既往の知見 ${ }^{3)}$ と一致する。また損傷度 $\mathrm{D}_{\mathrm{e}}$ は, 多段振幅に おいて一定振幅とみなせる振幅レベルごとにエネルギー評価法で求 めた損傷度であり, 最初の振幅レベルにおいては概衫 $D_{m}$ と一致し ているものの, 載荷が進むにつれ, 徐々に $\mathrm{D}_{\mathrm{m}}$ より小さくなる傾向 がみられる。これは，繰返し疲労によって軸材の面外変形が進み， エネルギー吸収性能が徐々に低下していく劣化現象と捉えられる。

また, 多段振幅を一つのランダム応答波形とみなし, 対数平均ひ ずみ振幅 $\Delta_{\mathrm{eq} 1} \varepsilon_{\mathrm{t}}$ を用いて平均振幅則で算定した損傷度 $\mathrm{D}_{\mathrm{e} 1}$ は, いず れの試験体も $D_{m}$ と比較して小さい值を示している。文献 14 では, 塑性ひずみ振幅に対する疲労曲線式の傾き（本論文の $\beta_{2}$ に相当）が 1.0 より小さくなるほど，Miner 則より平均振幅則の損傷度が低下 する傾向を示しており, 本試験体では $\beta_{2}=0.56$ であることから, 同 様の傾向を示したと考えられる。さらに, 累加平均ひずみ振幅 $\Delta_{\mathrm{eq} 2} \varepsilon_{\mathrm{t}}$ を用いて平均振幅則で算定した損傷度 $\mathrm{D}_{\mathrm{e} 2}$ は，いずれの試験体も $\mathrm{D}_{\mathrm{e} 1}$ より小さくなる傾向が見られた。

ここで, 載荷振幅の入力順序のみを入れ替えたペアとなる試験体 を比較する。ただし， 3.2 節で述べたように，試験機の制御能力の 関係で入力振幅にばらつきが生じたため, 得られた損傷度の絶対值 には入力振幅と入力順序のばらつきが両方含まれていると考えられ る。そこで, 入力順序によるばらつきのみを評価するため, $D_{m}$ に 対する $D_{\mathrm{e} 1}$ の比 $\left(\mathrm{D}_{\mathrm{e} 1} / \mathrm{D}_{\mathrm{m}}\right)$ を算定した結果を Table 4 および Fig.14 に示す。この $\mathrm{D}_{\mathrm{e} 1} / \mathrm{D}_{\mathrm{m}}$ を比較することにより，入力振幅によらず， 振幅に対する相対的なエネルギー吸収量の変化として, 入力順序が 平均振幅則の損傷度に与える影響を捉えることが可能と考えられる。

$\mathrm{F} 5 \sim \mathrm{F} 10$ について $\mathrm{D}_{\mathrm{e} 1} / \mathrm{D}_{\mathrm{m}}$ を比較すると, 大・小振幅の入力順序 による違いが大きく表れており, 先に大振幅を受けた F6,F8,F10 試 験体は，それぞれ F5,F7,F9 試験体に対して約 15\%低下している。 また，F11 と F12 では入力順序による差は見られなかったものの， いずれも大振幅から小振幅への減少載荷を含んでいることから, F6,F8,F10 と同程度となっている。さらに，ランダム波形で時間軸 のみを反転させた試験体 I1,I2 においては，入力順序の違いによる 差はほとんど見られなかった。 $D_{\mathrm{e} 1} / D_{\mathrm{m}}$ はいずれも $0.8 \sim 0.9$ の值と なっており, 前述した疲労曲線式の傾きによる低下率 14) と概数一致 する。時間軸反転載荷では，時間軸上で大振幅に相当するパルス的 な波形を生じる位置に違いはあるものの, 大振幅波形の前後に小振 幅波形が連続しており，また，大振幅の波数が少なかったことも，

入力順序による差が現れなかった要因と考えられる。

次に, 平均ひずみ振幅の違いが平均振幅則による損傷度評価に与 える影響を確認するため, 対数平均ひずみ振幅を用いた損傷度 $\mathrm{D}_{\mathrm{e} 1}$ に対する累加平均ひずみ振幅を用いた損傷度 $\mathrm{D}_{\mathrm{e} 2}$ の比 $\left(\mathrm{D}_{\mathrm{e} 2} / \mathrm{D}_{\mathrm{e} 1}\right)$ を Table 4 および Fig.14 に併せて示す。入力順序を入れ替えた試験体 について $\mathrm{D}_{\mathrm{e} 2} / \mathrm{D}_{\mathrm{e} 1}$ を比較すると, いずれも入力順序による差はほと
んど見られない。一方で, 多段振幅載荷で $\Delta \varepsilon_{\mathrm{t}} \fallingdotseq 3.0 \%$ を含む試験体 で $D_{\mathrm{e} 2} / D_{\mathrm{e} 1}$ が若干小さくなる傾向が見られることから, $D_{\mathrm{e} 2} / D_{\mathrm{e} 1}$ のば らつきは, 大振幅と小振幅の振幅比が影響していると推察される。

\section{4. 実大実験による妥当性検証}

\section{1 試験体}

基本モデル実験で大・小振幅の入力順序による損傷度影響が確認 されたため，座屈拘束力が相対的に小さくなる実大サイズ試験体に 対して，同様の損傷度影響評価を試みた。Fig.15 に示す試験体は， 基本モデル試験体に対し, 塑性化部長さが約 4 倍で, 補剛材の板厚 を $12 \mathrm{~mm}$ と薄くしたことにより，座屈拘束力（補剛材が塑性崩壊す るときの限界軸力の降伏軸力に対する安全率）は基本モデル試験体 の約 $1 / 2$ となっている。また, 補剛材の片側端面に塞ぎ板を設置し,

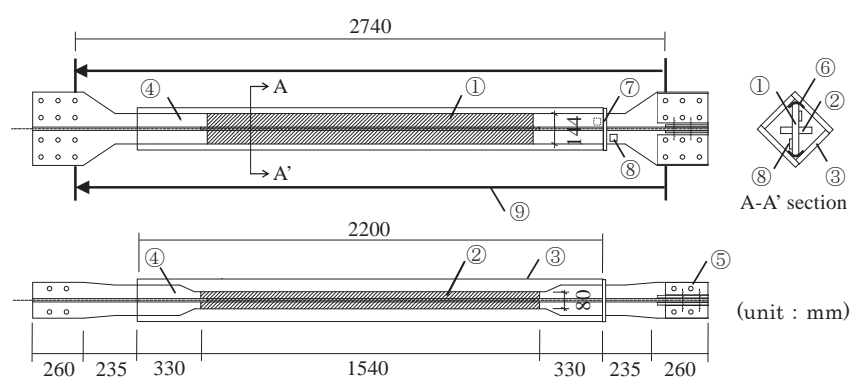

(1) $M$ ain axial member : $t=16$ (4) $E$ dge member : $t=16$ (7) Closing plate : $t=9$ (2) Sub axial member : $t=16 \quad$ (5)Bolt joint : $\varphi 24 \quad$ (8) Holding plate : $t=4.5$ (3) Restraint member : $\square 141 \times 12 t$ (6)Liner plate : $t=1.2$ (9)Displacement gauge

Fig.15 Shape of specimen (Full-scale size)

Table5 Results of material testing (Full-scale size)

\begin{tabular}{c|c|c|c|c|c|c}
\hline Member & M aterial & $\begin{array}{c}\text { Thickness } \\
(\mathrm{mm})\end{array}$ & $\begin{array}{c}\text { Y ield } \\
\text { Strength } \\
\left(\mathrm{N} / \mathrm{mm}^{2}\right)\end{array}$ & $\begin{array}{c}\text { Tensile } \\
\text { Strength } \\
\left(\mathrm{N} / \mathrm{mm}^{2}\right)\end{array}$ & $\begin{array}{c}\text { Y ield } \\
\text { Ratio } \\
(\%)\end{array}$ & $\begin{array}{c}\text { Elongation } \\
(\%)\end{array}$ \\
\hline A xial & LY 225 & 15.9 & 206.9 & 310.9 & 66.6 & 61.1 \\
\hline Edge & SN 490B & 16.1 & 376.4 & 530.4 & 71.0 & 28.4 \\
\hline Restraint & SM 490A & 11.6 & 353.7 & 526.9 & 67.1 & 28.4 \\
\hline
\end{tabular}

\begin{tabular}{c|c|c} 
Table6 & \multicolumn{2}{c}{ Loading pattern } \\
\hline $\begin{array}{c}\text { Test } \\
\text { B ody }\end{array}$ & $\begin{array}{c}\text { Loading } \\
\text { Pattern }\end{array}$ & $\begin{array}{c}\Delta \varepsilon \mathrm{t} \\
(\%)\end{array}$ \\
\hline \hline P1 & Constant & 0.5 \\
P2 & 2.0 \\
P3 & A mplitude & 3.0 \\
P4 & & 4.0 \\
\hline & Two-stage & \\
P5 & A mplitude & $0.5 \Leftrightarrow 3.0$ \\
& Repetition & \\
\hline
\end{tabular}

(unit : mm)

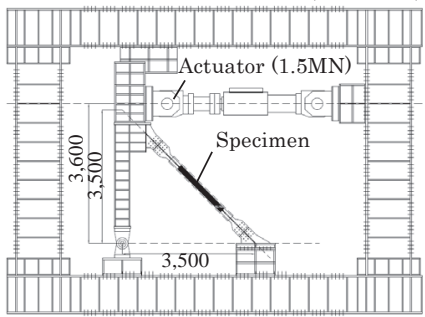

Fig.16 Loading system

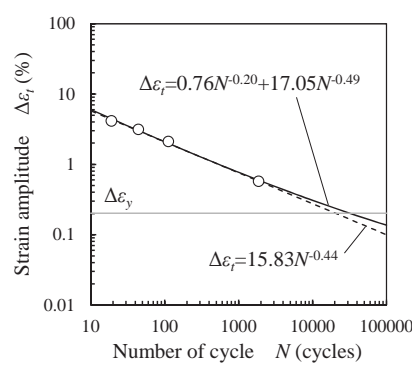

Fig.17 $\Delta \varepsilon_{t}-N$ relationship

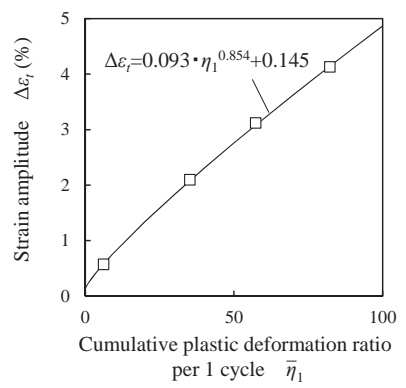

Fig.18 $\Delta \varepsilon_{t}-\bar{\eta}_{1}$ relationship 
この塞ぎ板を挟み込むように保持板を端部材に溶接することで, 補 剛材のずれを防止している。素材試験結果を Table5 に示す。

\section{2 一定振幅載荷実験}

Fig.15 に示寸試験体を用いた一定振幅載荷実験 $(\mathrm{P} 1 \sim \mathrm{P} 4)$ から, 改めて疲労曲線式を設定し, 軸材塑性化部の全ひずみ振幅 $\Delta \mathcal{E}_{\mathrm{t}}=0.5$ \%と $3.0 \%$ を交互に繰返す連続 2 段振幅載荷実験（P5）を行った。 載荷パラメータを Table6 に示す。載荷装置は, Fig.16 に示すフレ 一ム型治具に対して, 試験体を 45 度方向に高力ボルト接合で取り 付け， $1.5 \mathrm{MN}$ アクチュエータを用いて水平方向に載荷した。

一定振幅載荷実験で得られた全ひずみ振幅 $\Delta \varepsilon_{\mathrm{t}}$ と限界繰返しサイ クル数 $\mathrm{N}_{\mathrm{cr}}$ の関係 (プロット), および式(1), 式(2)の回帰式を Fig.17 に示す。ここに, 式(1)の定数は $C_{1}=0.76, C_{2}=17.05, \beta_{1}=0.20, \beta_{2}=$ 0.49, 式(2)の定数は $C=15.83, \beta=0.44$ とした。また, 基本モデル 実験と同様に, 1 サイクルあたりの平均累積塑性変形倍率 $\bar{\eta}_{1}$ と全ひ ずみ振幅 $\Delta \varepsilon_{\mathrm{t}}$ の関係（プロット）を, 以下の回帰式と併せて Fig.18 に示す。実験範囲において, 回帰式は良い一致を示している。

$\Delta \varepsilon_{\mathrm{t}}=0.093 \cdot \bar{\eta}_{1}^{0.854}+0.145$

\section{3 連続 2 段振幅載荷実験}

連続 2 段振幅載荷実験において, 振幅を切り替えるまでの繰返し サイクル数は, Miner 則を用いて算定される推定損傷度が約 0.1 と なるように， $\Delta \varepsilon_{\mathrm{t}}=0.5 \%$ に対し 250 サイクル， $\Delta \varepsilon_{\mathrm{t}}=3.0 \%$ に対し 5 サイクルと設定した。

振幅レベルを切り替えた際の 1 サイクル目の応力ーひずみ関係を

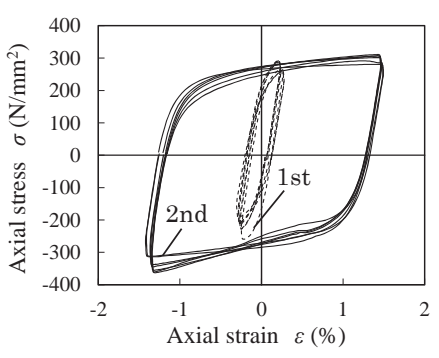

Fig.19 $\sigma-\varepsilon$ relationship
Fig.20 Progress of $\sigma_{\max } / \sigma_{y}$

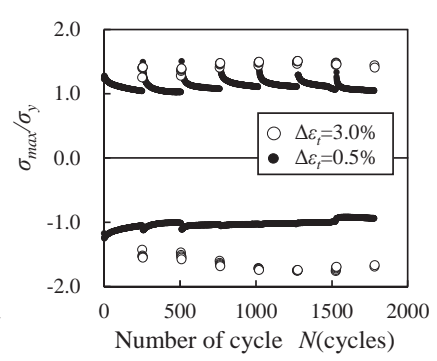

Fig.19 に, 全てのサイクルにおける最大応力の推移を Fig.20 に示 す。なお, 実大サイズ試験体を用いた実験においては, 負側を圧縮 としている。 $\Delta \varepsilon_{\mathrm{t}}=3.0 \%$ では, 繰返しにより剛性低下が早期に表れ, 履歴面積が小さくなっている。一方, $\Delta \varepsilon_{\mathrm{t}}=0.5 \%$ で, 1 回目の履歴 と比較して, 大振幅を経験した後の耐力低下が大きく表れており, 基本モデル実験と同様の傾向が見られた。なお, 圧縮側で耐力が増 加しているのは, 面外変形が卓越するとともに補剛材のずれ止めが 外れ，端部拡幅部と接触したことが原因である。

\section{4 多段入カレベル載荷実験}

次に, 3.4 節の想定地震波 OSA NS に対する時刻歴応答解析結果 から得られたランダム応答波形を用いて, 振幅レベルのみを変化さ せて入力順序を入れ替えた多段入力レベル載荷実験を実施した。試 験体形状および載荷装置は 4.2 節と同じとし, 入力波形は解析結果 の水平方向応答波形を取り出した。
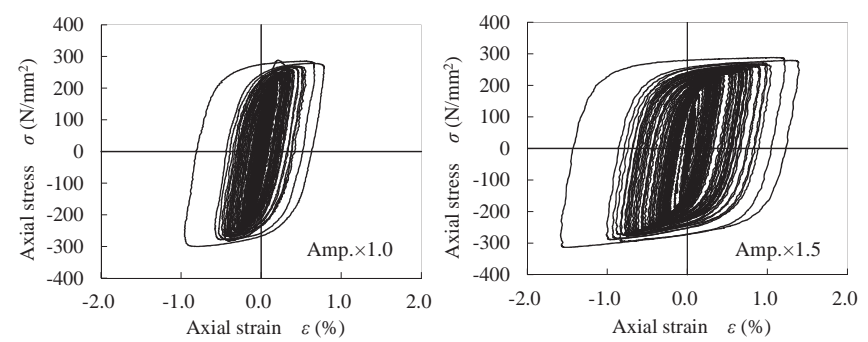

Fig. $21 \sigma-\varepsilon$ relationship (Input amplitude $\times 1.0 \Rightarrow \times 1.5$ )
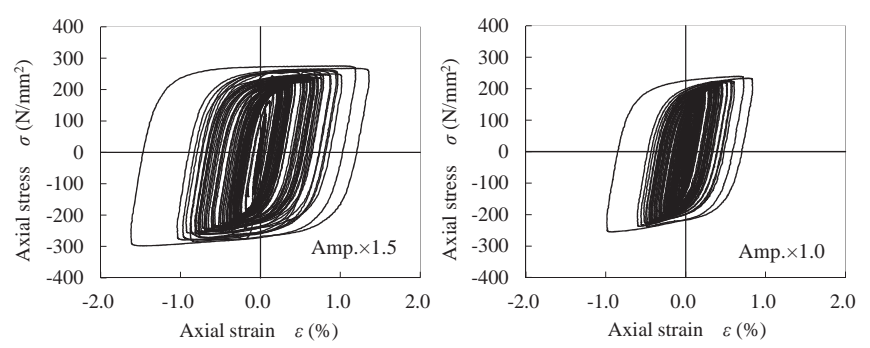

Fig. $22 \sigma-\varepsilon$ relationship (Input amplitude $\times 1.5 \Rightarrow \times 1.0$ )

Table7 Result of damage index for full-scale size

\begin{tabular}{|c|c|c|c|c|c|c|c|c|c|c|c|c|c|}
\hline $\begin{array}{l}\text { Loading } \\
\text { Pattern }\end{array}$ & $\begin{array}{l}\text { Test } \\
\text { Body }\end{array}$ & $\begin{array}{l}\Delta \varepsilon \mathrm{t} \\
(\%)\end{array}$ & $\begin{array}{c}\mathrm{n} / 2 \\
\text { (cycle) }\end{array}$ & $\eta$ & $D_{m}$ & $\mathrm{De}$ & $D_{e} / D_{m}$ & $\begin{array}{c}\Delta \Delta_{\mathrm{eq} 1} \varepsilon \mathrm{t} \\
(\%)\end{array}$ & $\mathrm{D}$ e 1 & $\begin{array}{c}\Delta_{\mathrm{eq} 2} \varepsilon \mathrm{t} \\
(\%)\end{array}$ & $D_{\text {e } 2}$ & $\mathrm{D}$ e $1 / \mathrm{D} \mathrm{m}$ & $\mathrm{D}$ e $2 / \mathrm{D}$ e 1 \\
\hline \multirow{4}{*}{$\begin{array}{l}\text { Constant } \\
\text { A mplitude }\end{array}$} & P1 & 0.57 & 1860 & 11418 & 0.97 & 1.01 & 1.04 & & & & & & \\
\hline & P2 & 2.1 & 112 & 3937 & 1.14 & 1.13 & 0.99 & & & & & & \\
\hline & P3 & 3.12 & 44 & 2521 & 1.10 & 1.09 & 0.99 & & & & & & \\
\hline & P4 & 4.13 & 19 & 1563 & 0.90 & 0.91 & 1.01 & & & & & & \\
\hline \multirow{15}{*}{$\begin{array}{l}\text { Two-stage } \\
\text { A mplitude } \\
\text { Repetition }\end{array}$} & \multirow{15}{*}{ P5 } & 0.58 & 250 & 1501 & 0.14 & 0.13 & 0.99 & \multirow{15}{*}{0.73} & \multirow{15}{*}{1.32} & \multirow{15}{*}{0.63} & \multirow{15}{*}{1.17} & \multirow{15}{*}{0.80} & \multirow{15}{*}{0.89} \\
\hline & & 2.91 & 5 & 333 & 0.11 & 0.13 & 1.26 & & & & & & \\
\hline & & 0.58 & 250 & 1603 & 0.14 & 0.14 & 1.06 & & & & & & \\
\hline & & 2.89 & 5 & 324 & 0.11 & 0.13 & 1.23 & & & & & & \\
\hline & & 0.59 & 250 & 1472 & 0.14 & 0.13 & 0.94 & & & & & & \\
\hline & & 2.83 & 5 & 322 & 0.10 & 0.13 & 1.25 & & & & & & \\
\hline & & 0.58 & 250 & 1399 & 0.14 & 0.12 & 0.92 & & & & & & \\
\hline & & 2.81 & 5 & 318 & 0.10 & 0.12 & 1.25 & & & & & & \\
\hline & & 0.59 & 250 & 1431 & 0.14 & 0.13 & 0.92 & & & & & & \\
\hline & & 2.80 & 5 & 314 & 0.10 & 0.12 & 1.24 & & & & & & \\
\hline & & 0.59 & 250 & 1433 & 0.14 & 0.13 & 0.91 & & & & & & \\
\hline & & 2.81 & 5 & 302 & 0.10 & 0.12 & 1.19 & & & & & & \\
\hline & & 0.64 & 250 & 1460 & 0.17 & 0.14 & 0.83 & & & & & & \\
\hline & & 2.93 & 2 & 112 & 0.04 & 0.05 & 1.04 & & & & & & \\
\hline & & Total & 1782 & 12323 & 1.65 & 1.73 & 1.05 & & & & & & \\
\hline \multirow{3}{*}{$\begin{array}{c}\text { Increase } \\
\text { Level of } \\
\text { A mplitude } \\
\end{array}$} & \multirow{3}{*}{ L1 } & Original & 2652 & 3598 & 0.43 & & & 0.63 & 0.34 & 0.53 & 0.30 & 0.79 & 0.89 \\
\hline & & A mp. $\times 1.5$ & 136 & 1905 & 0.34 & & & 1.13 & 0.30 & 0.97 & 0.26 & 0.88 & 0.87 \\
\hline & & Total & 788 & 5502 & 0.77 & & & - & 0.64 & - & 0.56 & 0.83 & 0.88 \\
\hline \multirow{3}{*}{$\begin{array}{c}\text { Decrease } \\
\text { Level of } \\
\text { A mplitude }\end{array}$} & \multirow{3}{*}{ L2 } & A mp. $\times 1.5$ & 135 & 1960 & 0.34 & & & 1.14 & 0.31 & 0.99 & 0.27 & 0.90 & 0.87 \\
\hline & & Original & 1180 & 6782 & 0.86 & & & 0.66 & 0.67 & 0.56 & 0.59 & 0.77 & 0.89 \\
\hline & & Total & 1315 & 8742 & 1.21 & & & - & 0.98 & - & 0.86 & 0.81 & 0.88 \\
\hline
\end{tabular}


先に原波（1.0 倍波）を 10 回入力後, 水平変位を 1.5 倍に拡幅した 波形（1.5 倍波）を入力した結果，3 回目の入力時に軸材の破断に至 った。そこで, 入力順序を変えて 1.5 倍波を 2 回入力後, 1.0 倍波 を繰返し入力した結果, 19 回目の入力で破断に至った。Fig.21,

Fig.22 に，各振幅レベル 1 回目の応力ーひずみ関係を示す。 1.5 倍 波の復元力特性は載荷順序によらずほぼ一致しているが, 1.0 倍波 では先に 1.5 倍波を入力した試験体 L 2 において, 履歴面積が小さ くなっている。これは, 基本モデル実験で見られた傾向と一致する。

\section{5 損傷度評価結果}

実大実験に対する損傷度評価結果をTable7およびFig. 23 に示す。 連続 2 段振幅載荷実験において, Miner 則評価による損傷度 $D_{m}$ が 1.0 を超えた要因の一つとして, 4.3 節で述べたように, 補剛材と端 部材との接触により, 軸力の一部が補剛材に流れ, 軸力材の軸力負 担が低減したことが考えられる。また，振幅レベルごとのエネルギ 一評価による $D_{\mathrm{e}}$ も, 最終の振幅レベルを除き, 繰返し疲労による低 下はほとんど見られず， $D_{m}$ をやや上回る結果となった。一方で， 連続 2 段振幅を一つのランダム応答波形とみなして算定した平均ひ ずみ振幅 $\Delta_{\mathrm{eq}} \mathcal{E}_{\mathrm{t}}$ による損傷度 $\mathrm{D}_{\mathrm{e} 1}$ は $\mathrm{D}_{\mathrm{m}}$ より 小さく, さらに累加平均 ひずみ振幅 $\Delta_{\mathrm{eq} 2} \mathcal{E}_{\mathrm{t}}$ による $\mathrm{D}_{\mathrm{e} 2}$ は $\mathrm{D}_{\mathrm{e} 1}$ より小さく算定されており,この 傾向は基本モデル実験結果と一致する。

次に, $D_{\mathrm{e} 1} / D_{\mathrm{m}}$ を比較した結果を Table7 および Fig.24 に示す。 連続 2 段振幅載荷実験においては, 大振幅を先に入力したペアとな る試験を実施していないため, 入力順序による影響を単純比較する ことはできないが， $\mathrm{D}_{\mathrm{e} 1} / \mathrm{D}_{\mathrm{m}}$ が約 0.8 と小さくなる傾向は，大振幅か ら小振幅への減少載荷を含む基本モデル実験結果と概ね一致する。 多段入力レベル実験においては，先に大振幅である 1.5 倍波を入力 した試験体 $\left(\mathrm{L}_{2}\right)$ の方がやや $\mathrm{D}_{\mathrm{e} 1} / \mathrm{D}_{\mathrm{m}}$ の低下が大きい傾向は見られた が, その差はわずかであった。小振幅に相当する 1.0 倍波において, 応力低下による復元力特性に違いが見られたものの, 全ひずみ振幅
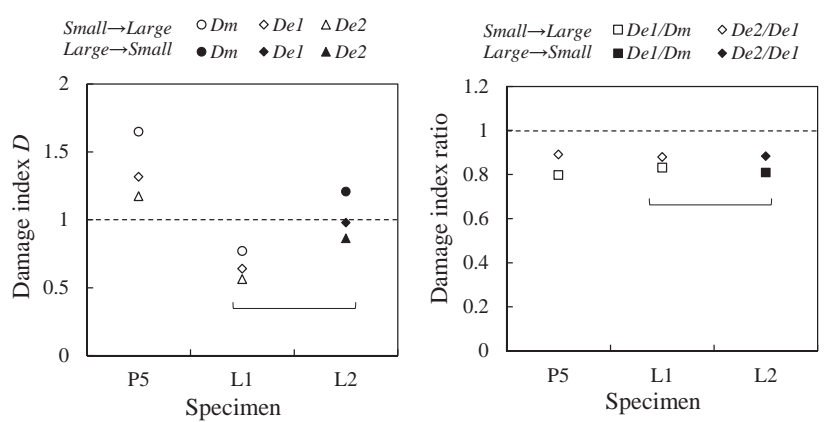

Fig.23 Comparison of $D$

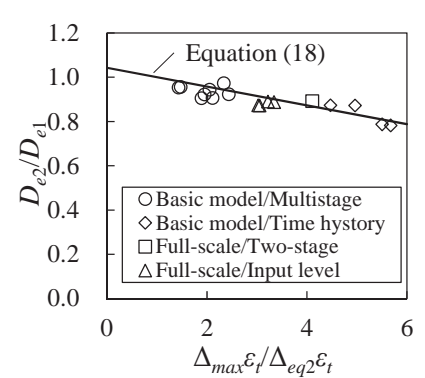

Fig.25 $D_{e 2} / D_{e 1}-\Delta_{\max } \varepsilon_{t} / \Delta_{e q 2} \varepsilon_{t}$ relationship
Fig.24 Comparison of $D$ ratio

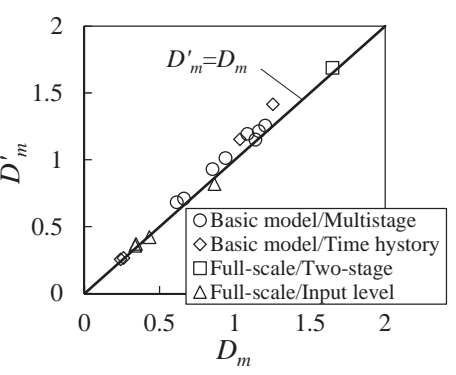

Fig.26 $D_{m}^{\prime}-D_{m}$ relationship
がやや大きくなったことにより, エネルギー吸収量の差として現れ なかったことが要因と考えられる。

さらに, 平均ひずみ振幅の与え方による影響を確認するため, 多 段入力レベル実験において $D_{\mathrm{e} 2} / D_{\mathrm{e} 1}$ を比較すると, 試験体 L1,L2 で 差が見られないことから, 入力順序による影響はないと言える。ま た, 連続 2 段振幅載荷実験における $\mathrm{D}_{\mathrm{e} 2} / \mathrm{D}_{\mathrm{e} 1}$ は, 最大・最小ひずみ の振幅比が近い基本モデル試験体 $\mathrm{F} 11, \mathrm{~F} 12$ と同等の值を示した。

そこで, 波形中に含まれる振幅比の指標として, 累加平均ひずみ 振幅 $\Delta_{\mathrm{eq} 2} \mathcal{E}_{\mathrm{t}}$ に対する最大ひずみ振幅 $\Delta_{\max } \mathcal{E}_{\mathrm{t}}$ の比をとり, $\mathrm{D}_{\mathrm{e} 2} / D_{\mathrm{e} 1}$ と の関係を比較した。結果を Fig. 25 に示寸。両者の間には, 直線的な 比例関係があることが見て取れる。2.2 節で述べたように, 一定振 幅載荷では $\Delta_{\mathrm{eq} 1} \varepsilon_{\mathrm{t}}=\Delta_{\mathrm{eq} 2} \mathcal{E}_{\mathrm{t}}\left(=\Delta_{\max } \varepsilon_{\mathrm{t}}\right)$ となることから, $\Delta_{\max } \varepsilon_{\mathrm{t}} / \Delta_{\mathrm{eq} 2} \varepsilon_{\mathrm{t}}=1$ のとき $D_{\mathrm{e} 2} / D_{\mathrm{e} 1}=1$ を通る直線として, 下式で回帰した。

$$
\frac{D_{\mathrm{e} 2}}{D_{\mathrm{e} 1}}=-0.042 \times \frac{\max \Delta \varepsilon_{\mathrm{t}}}{\Delta_{\mathrm{eq} 2} \varepsilon_{\mathrm{t}}}+1.042
$$

Fig.25 に示す式(18)の回帰式は, 実験結果とのばらつきはあるも のの, 載荷中に含まれる振幅比が大きくなるほど, $D_{\mathrm{e} 2} / D_{\mathrm{e} 1}$ が低下 する傾向を表現できている。

ここで, $D_{\mathrm{e} 1} / D_{\mathrm{m}}=\kappa_{1}, D_{\mathrm{e} 2} / D_{\mathrm{e} 1}=\kappa_{2}$ と置くと, 下式を用いて, 累加 平均ひずみ振幅 $\Delta_{\mathrm{eq} 2} \varepsilon_{\mathrm{t}}$ を用いた平均振幅則による損傷度 $\mathrm{D}_{\mathrm{e} 2}$ から, Miner 則による損傷度 $D_{m}$ を算定できる。

$$
D_{m}=\frac{D_{m}}{D_{e 1}} \cdot \frac{D_{e 1}}{D_{e 2}} \cdot D_{e 2}=\frac{D_{e 2}}{\kappa_{1} \cdot \kappa_{2}}
$$

ここで, 今回の実験結果から, 安全側を見て $\kappa_{1}=0.8$ (ただし, 減 少載荷が含まれる場合は低下率を考慮して $\left.\kappa_{1}=0.8 \times 0.85\right)$ と仮定し， 式(18)の回帰式を用いて算定される $\kappa_{2}$ を式(19)に代入して得られる 推定損傷度を $D_{m}^{\prime}$ と定義する。推定損傷度 $D_{m}^{\prime}$ と Miner 則で直接算 定した $D_{m}$ を比較して Fig. 26 に示す。今回の実験範囲内に限った参 考值ではあるが， $D_{m}^{\prime}$ は $D_{m}$ と良い一致を示すことが分かる。このこ とから, 入力順序の影響と平均ひずみ振幅の与え方による影響を加 味した補正により, 累加平均ひずみ振幅 $\Delta_{\mathrm{eq} 2} \varepsilon_{\mathrm{t}}$ を用いた平均振幅則 による損傷度 $\mathrm{D}_{\mathrm{e} 2}$ から, Miner 則による損傷度 $\mathrm{D}_{\mathrm{m}}$ を精度よく推定 できる可能性があることを確認できた。

\section{FEM 解析による復元力特性の変化要因推定}

基本モデル実験および実大実験において確認された大・小振幅の 入力順序による復元力特性の変化要因を確認寸るため, 軸材塑性化 部長さと載荷順序をパラメータとした大変形弾塑性 FEM 解析を実 施した。解析パラメータを Table8 に示す。解析コードは ABAQUS を用いた。各ケースを相対的に比較するため, 軸材の履歴則には簡 易な移動硬化モデルを用い, ポアソン比 0.3 , 降伏強度および引張 強度は規格下限值として, $\sigma_{\mathrm{y}}=205 \mathrm{~N} / \mathrm{mm}^{2}, \sigma_{\mathrm{u}}=300 \mathrm{~N} / \mathrm{mm}^{2}$, ヤング 率 $\mathrm{E}_{1}=2.05 \times 10^{5} \mathrm{~N} / \mathrm{mm}^{2}$, 二次勾配 $\mathrm{E}_{2}=\mathrm{E}_{1} / 60$, 引張強度到達以後は $E_{1} / 1000$ の勾配が続くものとした。Fig.27に示すように, 軸材, 端 部材および補剛材を四角形要素のシェルモデルとし, 補剛材隅角部 と主軸材角部との間は接触要素として, 材軸（X 軸）直交方向のク リアランスがゼロとなった時に圧縮力のみを伝える機構とした。端 部材両端は剛体面とし, $\mathrm{Z}$ 軸回転のみ自由とした。初期不整は固有 值解析で得られた 1 次モード形を用いて, 最大不整量が塑性化部長 さの $1 / 1000$ となるように設定した。入力振幅は, 推定損傷度が概 
Table8 Parameter for FEM analysis

\begin{tabular}{|c|c|c|c|c|}
\hline $\begin{array}{l}\text { Case } \\
\text { No. }\end{array}$ & $\begin{array}{l}\text { Length of plasticizing } \\
\text { section } L(\mathrm{~mm})\end{array}$ & $\begin{array}{l}\text { Cross section of } \\
\text { axial member }\end{array}$ & $\begin{array}{l}\text { Cross section of } \\
\text { restraint member }\end{array}$ & L oading pattern \\
\hline 1 & \multirow{2}{*}{372} & \multirow{2}{*}{$124^{\mathrm{W}} \times 90^{\mathrm{H}} \times 16^{\mathrm{t}}$} & \multirow{2}{*}{$\square 141 \times 19^{t}$} & $\Delta \varepsilon_{\mathrm{t}}=1.0 \% \rightarrow 3.0 \%$ \\
\hline 2 & & & & $\Delta \varepsilon_{\mathrm{t}}=3.0 \% \rightarrow 1.0 \%$ \\
\hline 3 & \multirow{2}{*}{1540} & \multirow{2}{*}{$144^{W} \times 80^{H} \times 16^{t}$} & \multirow{2}{*}{$\square 141 \times 12^{t}$} & $\Delta \varepsilon_{\mathrm{t}}=1.0 \% \rightarrow 3.0 \%$ \\
\hline 4 & & & & $\Delta \varepsilon_{\mathrm{t}}=3.0 \% \rightarrow 1.0 \%$ \\
\hline
\end{tabular}

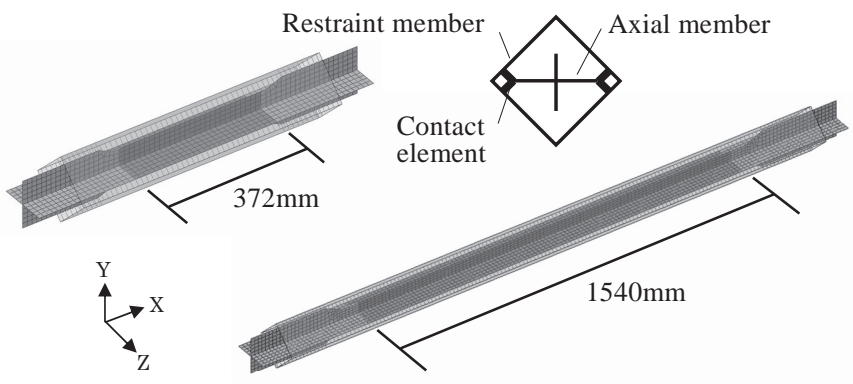

Fig.27 Analytical model

放等しくなる小振幅（ $\Delta \varepsilon_{\mathrm{t}}=1.0 \% ）$ を 20 回，大振幅（ $\Delta \varepsilon_{\mathrm{t}}=3.0 \% ）$ を 2 回とした。

Fig.28 に, Case.1,2 における各振幅レベルでの載荷 1 回目の最大 引張時におけるミーゼス応力コンターを，変形図と併せて示す。な お, 変形量は 10 倍に拡大している。 $\Delta \varepsilon_{\mathrm{t}}=3.0 \%$ 時の結果を比較する と, 載荷順序によらず，いずれも塑性化部全体で一様な応力状態と なっているが， $\Delta \mathcal{E}_{\mathrm{t}}=1.0 \%$ を比較すると，先に $\Delta \mathcal{E}_{\mathrm{t}}=3.0 \%$ の載荷を受 けた Case.2 の場合に, 圧縮時に生じた軸材の面外変形が最大引張 時も残留変形として残っており，局所的に応力が低下していること が分かる。これは, 基本モデル実験の大振幅を先に受けた試験体に おいて, その後の小振幅で応力が低下した結果と一致する。

Fig.29 に, Case.3,4 における各振幅レベルの載荷 1 回目と最終回 目の最大圧縮時における相当塑性ひずみコンターを時系列に並べて 示す。初期載荷時は, Case.3,4 で振幅の大きさが異なるものの，い ずれも 1 次の変形モードを呈しており，ひずみも一様に分布してい る。しかしながら，推定損傷度が概称等しくなる初期振幅レベル最 終時で比較すると, 載荷振幅の小さい Case.3 において局所的なひ ずみ集中が早期に表れている様子が分かる。一方，先に大振幅を受 ける Case.4 では, 面外変形は生じているものの, ひずみ集中は小 さい。さらに, 振幅レベルを変えた後の 1 回目でも, 特に Case 3 に おいて，ひずみ集中がそのまま移行して蓄積されていく様子が分か る。基本モデル実験の小振幅後の大振幅時に，ひずみがゼロとなる 近傍で剛性・耐力低下が生じた要因と考えられる。このように，大・ 小振幅の入力順序によって復元力特性が変化する要因として, 大振 幅を先に受けた後の残留変形による応力低下，および小振幅を先に 受けた際の局所的なひずみ集中の影響が考えられる。

\section{6. まとめ}

十字型断面の軸材と溶接組立箱形断面の補剛材で構成される座屈 拘束ブレースを対象に，大・小振幅の入力順序を入れ替えた各種実 験および解析を実施し, Miner 則に対する平均振幅則の損傷度の比 を比較することで, 変位振幅の入力順序が平均振幅則を用いた損傷 度評価に与える影響を確認した。また，エネルギー評価法の一つと
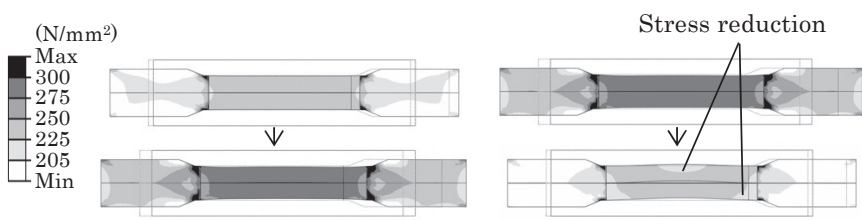

(a)Case.1 $\left(\Delta \varepsilon_{t}=1.0 \% \rightarrow 3.0 \%\right)$ (b)Case. $2\left(\Delta \varepsilon_{t}=3.0 \% \rightarrow 1.0 \%\right)$

Fig.28 Contour of von Mises stress at maximum tensile load

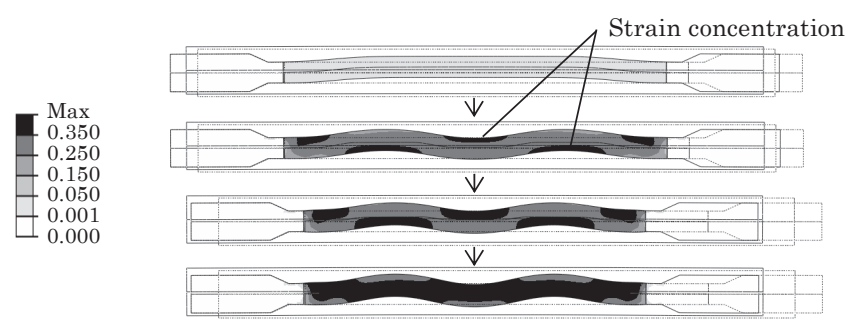

(a)Case.3 $\left(\Delta \varepsilon_{t}=1.0 \% / 1\right.$ st $\rightarrow 20$ th $\rightarrow \Delta \varepsilon_{t}=3.0 \% / 1$ st $\rightarrow 2$ nd $)$

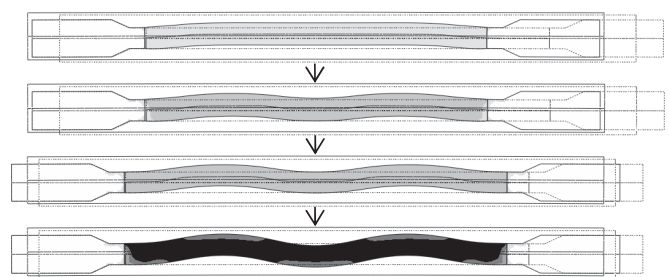

(b)Case.4 ( $\Delta \varepsilon_{t}=3.0 \% / 1 \mathrm{st} \rightarrow 2 \mathrm{nd} \rightarrow \Delta \varepsilon_{t}=1.0 \% / 1 \mathrm{st} \rightarrow 20$ th)

Fig.29 Contour of equivalent plastic strain at maximum compressive load

して提案した平均振幅則において, 平均振幅の与え方の違いが損傷 度に与える影響を確認した。今回実験の範囲内ではあるが，得られ た知見を以下に示す。

1）大・小振幅の入力順序を入れ替えた試験体について, エネルギ 一評価法（対数平均ひずみ振幅を用いた平均振幅則）により求 めた損傷度 $\mathrm{D}_{\mathrm{e} 1}$ と, Miner 則評価により求めた損傷度 $\mathrm{D}_{\mathrm{m}}$ の比 （以下，損傷度比 $\mathrm{D}_{\mathrm{e} 1} / \mathrm{D}_{\mathrm{m}}$ ) は, 先に大振幅を受けた場合に, 先に小振幅を受けた場合に比べて約 $15 \%$ 低下した。

2）入力順序による損傷度比 $D_{\mathrm{e}} / D_{\mathrm{m}}$ の違いは, 多段になるほど小 さくなり，振幅の増加・減少を含む入力に対してはほとんど影 響が見られなかった。これは, 最大振幅の前後に小振幅が連続 する地震動入力においても同様であった。

3）累加平均ひずみ振幅を用いた平均振幅則による損傷度 $\mathrm{D}_{\mathrm{e} 2}$ は, 対数平均ひず夕振幅を用いて算定した損傷度 $\mathrm{D}_{\mathrm{e} 1}$ よりも小さく 算定される。その損傷度比 $\mathrm{D}_{\mathrm{e} 2} / \mathrm{D}_{\mathrm{e} 1}$ は, 大 小振幅の入力順序 による差は見られず, 波形中に含まれる最大ひずみ振幅 $\Delta_{\max } \varepsilon_{\mathrm{t}}$ と累加平均ひずみ振幅 $\Delta_{\mathrm{eq} 2} \varepsilon_{\mathrm{t}}$ の比と相関が見られた。

4） FEM 解析の結果から, 小振幅時の局所的なひずみ集中や大振 幅時の残留変形が, その後の復元力特性の変化（エネルギー吸 収量の低下）に影響していると考えられる。

今後の課題として, 異なる地震動特性やブレース形状に対する検 討を加えるとともに，最大ひずみ振幅から累加平均ひずみ振幅ある いは対数平均ひずみ振幅を簡易に推定する手法の構築を進める予定 である。 
本報告は, 東京理科大学北村研究室, JFE スチール(株), JFE シ ビル(株)による共同研究の成果の一部を用いたものです。ここに記 して，感謝の意を示します。

\section{参考文献}

1）南海トラフ巨大地震対策について (最終報告), 内閣府中央防災会議, 2013.5

2）首都直下地震の被害想定と対策について（最終報告），内閣府中央防災会 議, 2013.12

3）瀬戸洋平，中込忠男，塩川直：極低降伏点鋼の 2 段多重振幅における累積 疲労損傷に関する実験的研究，日本建築学会構造系論文集，第 75 巻，第 653 号, pp. 1265-1270, 2010. 7

4）小野喜信，中山信雄，金子洋文：H形鋼座屈補剛制震ブレースの損傷度評 価に関する研究, 日本建築学会大会学術講演梗概集, C- 1 , 構造III, pp. 1023-1024, 2005. 9

5）寺田岳彦，佐武直紀，堀江竜巳，真瀬伸治，小川雄一郎，磯田和彦：溝形鋼 で補剛された座屈拘束ブレースダンパーの低サイクル疲労特性と累積損 傷度評価, 日本建築学会技術報告集, 第 16 号, pp.111-116, 2002. 12

6）小山雅人，青木博文：繰返し変形を受ける鋼部材の累積損傷評価指標に関 する研究，日本建築学会構造系論文集，第 562 号, pp. 159-166, 2002. 12

7）竹内徹, 井田茉利, 山田哲, 鈴木一弁：変動歪振幅下における座屈拘束ブ レースの累積塑性変形性能予測, 日本建築学会構造系論文集, 第 586 号, pp. 203-210, 2004. 12

8）日本建築学会編：鋼構造制振設計指針，丸善出版, 2014. 11

9）秋山宏：建築物の耐震極限設計 第 2 版，東京大学出版会, 1987

10) 植木卓也, 加村久哉, 山路宗忠, 北村春幸, 佐藤大樹, 西井宏安：長周期地 震動を受ける座屈補剛十字ブレースダンパーの性能評価（その 1〜その 3), 日本建築学会大会学術講演梗概集, C-1, 構造III, pp. 945-950, 2010.9

11) 植木卓也, 加村久哉, 山路宗忠, 北村春幸, 佐藤大樹, 西井宏安：座屈拘束 十字ブレースダンパーのランダム応答波形に対する疲労損傷度評価，日 本建築学会大会学術講演梗概集, C-1, 構造III, pp. 853-854, 2011. 8

12) S.S.Manson: Thermal Stress and Low Cycle Fatigue, McGraw-Hill, 1966 Engineering ASME, pp. 565-571, 1961. 12

13) L.F.Coffin Jr: Experimental Support for Generalized Equation Predicting Low Cycle Fatigue, Journal of Basic Engineering, Trans ASME, Series D, pp. 533-537, 1962. 12

14) R.Matsui, T.Takeuchi: Cumulative Deformation Capacity of Buckling Restrained Braces Taking Local Buckling of Core Plates into Account, Proceedings of 15WCEE (Lisbon), 2012. 9 


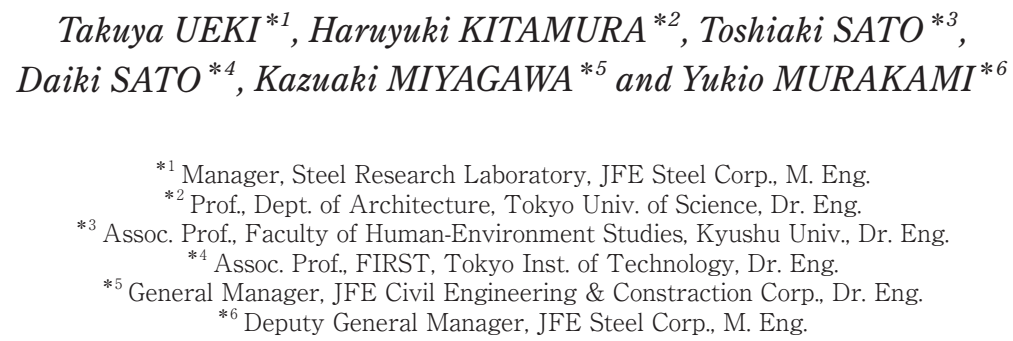

In recent years, buildings in Japan have been required to have high earthquake resistance that can be used continuously after the large-scale earthquakes occurred. In order to achieve this, the damage control design that allows to prevent the damage of main structure by absorbing the seismic energy in damping devices is effective. In addition, it is important to judge appropriately the damage state of the damping devices after the earthquake occurs.

The Miner's rule has been widely used as the damage evaluation for the random waveform, including the plastic region. On the other hand, the damage evaluation method using the quantity of total energy absorption is considered to be a simple method in comparison with the Miner's rule. Therefore, the authors proposed the average amplitude method as one of the energy evaluation method that can evaluate equivalent to Miner's rule. In this method, the random waveform is replaced by a constant average amplitude waveform so that the total energy absorption becomes equal. However, it was confirmed that there was some difference compared with the damage degree calculated by the Miner's rule.

In this paper, it aims to clarify the influence on the damage degree by the input order of the magnitude of strain amplitude and the difference in the calculation method of the average strain amplitude. The buckling restrained brace (BRB) to be evaluated is composed of a cross-shaped axial member using a low yield strength steel and restraint member of the welded box-section.

First, the basic model specimens which exclude the influence of the buckling restraining capacity by shortening the length of the plasticized region of the axial member and by increasing plate thickness of the restraint member is prepared. Then, the multistage amplitude loading tests in which the input order is switched and the dynamic loading tests by the response waveform in which only time axis is reversed are carried out.

Next, using the real-size specimens, the continuous two-stage amplitude loading tests in which large and small strain amplitude are alternately repeated and the dynamic loading tests in which the input order of magnitude of strain amplitude is exchanged are conducted.

Furthermore, it is evaluated that the influence on the strain behavior of the BRB by the input order of large and small amplitudes using FEM analysis.

The main results in this paper are summarized as follows:

1) The ratio of the damage degree obtained by the energy evaluation method (average amplitude method using logarithmic average strain amplitude) to the damage degree obtained by Miner's law is decreased by about $15 \%$ more when receiving the large amplitude first.

2) The order of the input amplitude including both the increase and the decrease like a seismic wave has little influence on the above damage degree ratio.

3) The damage degree by the average amplitude method using the cumulative average strain amplitude is calculated to be smaller than the damage degree calculated using the logarithmic mean strain amplitude.

4) As a result of FEM analysis, it is considered that the local strain concentration by small amplitude input and the residual deformation by large amplitude input influence the change of the restoring force characteristic after that. 